\title{
Post-Indiginist Realism in Modern African Drama
}

\author{
Isaiah U. Ilo \\ http://dx.doi.org//10.4314/ujah.v17i 2.5
}

\begin{abstract}
This paper highlights a literary style in which African dramatists compose in current diction and express themselves in a contemporary mode. The approach, identified in this essay as Post-indiginist Realism or Aesthetics, represents a departure from a celebrated method in which African dramatists privileged their culture or indigenous traditions in foreign language plays in the spirit of cultural nationalism. The main objective of this essay is to explain the Postindiginist concept, and thereafter examine some examples of the approach.
\end{abstract}

\section{Introduction}

Up to the present time, the aesthetic norm for African literature is composition in a colonial language based on traditional themes, local symbols, and native expressions. The Festival of Black and African Arts and Culture (FESTAC) held in 1977 in Lagos, Nigeria, articulated a definition of African literature that was widely accepted among African writers and scholars. According to the colloquium, the objective of modern African literature in colonial languages is to express an African content in the medium of a European language such as English or French. The African content consists of five indiginist (native) elements, namely: The writer must: 1) be African, 2) use traditional themes from oral literature, 3) use African symbols, 4) use linguistic expression taken from African languages, and 5) use local imagery, that is, images from immediate environment (Amoda 201). The 
resources of traditional African oral literature, such as myths, legends, folk tales, poetry, and proverbs, therefore constitute the African brand in colonial-language literature. Hence, African literary and critical aesthetics, from Africanist to Postcolonial to Afro-centric viewpoints, recognize artistically applied content of indigenous substance in the adopted foreign languages as canon of modern African literature. The indiginist style has held sway as the authentic African literary aesthetic. And post-colonial criticism, which emerged in the West as the most popular critical approach to African literature, has explained the style in terms of the colonised responding to their colonisers, writing back, and appropriating the coloniser's language. Postcolonial reading seeks, in texts from once colonised people, the depiction of the colonial presence, and how such presence is resisted or accommodated through the writing. But, as Anthony Chennells has noted, "the value of post-colonialism as a theoretical category has been heavily contested ever since the term was first formulated" (109). Post-colonialism privileges the colonial episode, making it the central issue of the world's history. In the words of Anne McClintock, too great an emphasis on colonialism marks a "recentering of global history around the single rubric of European time" (qtd. in Chennells, 109).

African writers prefer a classification of their works as "post-independence" instead of "post-colonial", because "post-independence" emphasizes the people's responsibility to themselves over the paternalistic, never-ending "postcolonial." The Nigerian writer and critic, Tanure Ojaide, has remarked that "writers in Africa have moved from putting blame for their fate on colonialists to taking their fate in their own hands" (210-214). Indeed, African literature might have been written in the past in response to colonialism, but today there are writers to whom colonialism does not hold as much significance as other urgent issues. Nevertheless, the 
privileging of ethnic culture in African creative writing, which arose from the circumstances of the nationalist struggle, has continued to the present day with the writers valorizing African myths, rituals and traditions in many of the works. As noted by a panel of judges of the Nigeria Prize for Literature, there is a general trend among the writers "to go back to African traditional cultures in search of solutions to modern social problems" (Nigeria LNG Limited, Report 2006 < www.nlng.com/PageEngine.aspx?\&id=93>). After examining entries of 77 plays, the panel observed that some writers seem to assume that patronizing African traditional cultures inevitably means digging up forms of traditional worship with all its rituals and paraphernalia. It regretted that modern themes did not feature too strongly in those entries, especially technology as well as the modern religions. "When some of the playwrights address contemporary problems, they attempt to solve such problems by going back to traditional roots" (NLNG Report 2006 www.nlng.com/PageEngine.aspx?\&id=93).

The Indiginist approach entails a strategy to indiginise a foreign language (for example Standard English) with untranslated words, proverbs, metaphor, simile and other devices from an African language (for example Igbo). A study of this approach will involve examining how both languages were conjoined in a text. Ashcroft, et al explain this style of writing as "the appropriation and reconstitution of language of the centre, the process of capturing and remolding the language to new usages" (37). Appropriation brings the colonial language under the control of the speech habits of the local language, conveying "in a language that is not one's own a spirit that is one's own" (Raja Jao qtd in Ashcroft, 38). The strategies of appropriation are given as glossing, syntactic fusion, untranslated words, inter language, code switching and mothertongue transcription. 
This approach to writing came to be labeled "transliteration," meaning "literal translation" - a procedure for introducing tropes and idioms from an African ethnic language into English through a commutation of equivalent words. Thus, the Igbo idiom "Were ire gi guo eze gi," which means the same as the English idiom "Read between the lines," can be introduced into an English text as "count your teeth with your tongue." The Igbo words are replaced by equivalent English words, but the idiom remains an Igbo cultural artifact (Onwuemene 1055-1066). The characteristic literary artifacts produced by transliteration are of three principal types: 1. Target-language expressions cast in the formal mold of source-language counterparts; 2. Sourcelanguage loanwords introduced into the target-language text; 3 . Source-language idioms and tropes (and sometimes sourcelanguage lexical collocation norms) introduced into the targetlanguage text (Onwuemene 1059). African playwrights that used this approach in some plays include Wole Soyinka (Death and the King's Horseman), Ola Rotimi (The Gods are not to Blame), and Sonny Oti (The Old Masters). Others are Joan Kivanda (Stori Ya), Tololwa Mollel (Pullyupullus), Austin Buckenya (The Bride), Francis Imbuga (Aminata), and Patrick Mangeri (Operation Mulungus).

In his play, The Old Masters, Sonny Oti applied transliteration to influence Standard English with the resources of Igbo speech practices. The play is set in OkeIgbo, a community in South Eastern Nigeria, at the time of British rule. It dramatizes the changes and conflicts that resulted from the presence of the White colonial master. In the play, the tradition of slavery has been disrupted and there are tragic outcomes on both sides as the slaves attempt to assert their freedom under the protection of the White man, and the freeborn, on the other hand, forcefully insist on keeping the tradition, including burying their dead ruler with a number of 
slaves. The slaves are represented by Daniel and Chidi, who have superficially embraced Christianity in order to get the support of the new masters for their freedom, while the freeborn are represented by Ukwu and Okereke, who are diehards of tradition. The plot is woven around events leading up to the death and burial of Mazi Oji-Okoro, a patriarch of the community. The traditional milieu is equally evoked through drumming, dances, masquerades, and religious chants. The linguistic devices used in the play include untranslated words, proverbs, metaphors and similes (Oti, The Old Masters).

There are, however, problems associated with transliteration. A writer is to first of all think in the mother tongue and then transliterate into English, and this means that writers who cannot use the mother tongue are handicapped in this regard. Ability to reflect indigenous traditions most effectively in transliterated works, on the part of African writers, depends on having a consciousness that is firmly rooted in Africa. But writers with such deep roots in the indigenous traditions are difficult to find. For instance, $\mathrm{Zulu}$ Sofola, Nigeria's first female playwright, expressed doubts over the ability of African writers to effectively create the original native speech patterns of their African characters in the English works. Sofola believed that most African writers are not well-off in the knowledge of their African language, nor are they informed on the thought, social order, philosophy and consciousness which African languages reflect (168-169). Secondly, there is evidence that transliteration poses comprehension problem to readers or audience members who are not familiar with the source culture. Abiola Irele has called this "the problematic relation that obtains between an African work in a European language and the established conventions of Western literature" (xiii). Ojaide illustrated this problem with his experience in teaching the text of Wole Soyinka's 
play, Death and the King's Horseman, in two American universities. He says that "While Soyinka is able to blend Yoruba thoughts into English effortlessly; students have problems with the indigenous background of his voice" (211). Soyinka's Yoruba-English poses problems to the American readers because of their lack of familiarity with the language systems of another culture:

The cultural signs in African literary works can then be said to have opposite values for two categories of readers: positive, for those who know the two languages involved (the contextually bilingual), and negative, for those who know English and not the writer's native language (the contextually monolingual). Ashcroft et al noted that cultural signs in crosscultural texts create an "experiential gap" for the contextually monolingual (66). For such readers, the signs are merely metonyms for vaguely perceived cultural differences that cannot be truly appreciated and that irritatingly impede full comprehension. Contextually monolingual readers therefore prefer to encounter as few of such signs as possible (Onwuemene 209). Thus Africa's ethno-texts, which ostensibly targeted the West as cultural ambassadors for the continent, rather turn out to be cultural enigmas to the foreigners. For they need to first learn the language, conventions, allusions, and cultural assumptions of the source culture in order to meaningfully appreciate just one of the texts.

\section{From Indiginist to Post-indiginist Aesthetics}

In proposing a shift from an indiginist to a Postindiginist paradigm, I argued in a previous paper, "Language in Modern African Drama" (Ilo $<$ http://docs.lib.purdue.edu/clcweb/vol8/iss4/1 >), that the changing context of African literature demands corresponding alteration in the current critical and literary aesthetic practices. An alternative paradigm is desirable because it is unsuitable to 
continue to apply the literary standards of anti-colonial literature to writings of a different era. There has now arisen a new generation of African writers who cannot apply the same aesthetics as the older generation that had closer contact with the African linguistic and oral traditions and faced an obligation to tackle colonialism. I equally contended that the oral tradition of proverbs, riddles, ballads, and stories from which modern African literature draws is often spoken of as though such tradition is an exclusive patent of Africa. It seems easily forgotten that other societies had similar traditions in their pre-literate era, which came to feature in their written literature. The ancient Greek plays for instance drew from the myths, legends and stories of an oral tradition. Just as western societies have come through the pre-literate, pre-modern and modern phases, and each phase has had its characteristic artistic imprint, African society and literature are similarly evolving. It is natural therefore if in the phase of transiting from a pre-literate oral tradition, emergent African literature is marked by a content of oral tradition. But such content, which is now hailed as the unique identity of African literature, is only a passing phase, because the further a society moves from its pre-literate past and oral traditions, the less such background exacts an influence on its contemporary literature. As writers emerge from a growing number of Africans who no longer have an African language as a mother tongue, that influence will be further eroded. The paper also reasoned that Western universalism which African writers sought so passionately to counter by deliberately projecting an Afrocentric worldview through creative writing is today a fading ideology and this should motivate a reassessment of a subsisting critical and aesthetic standard that is almost wholly based on cultural nationalism. In a postmodern multicultural context, culture is no longer defined as universal but as diverse, since all peoples have their own cultures. 
Furthermore, Tanure Ojaide says that today's generation of African writers "have become part of the worldwide phenomena of migration and globalization with the attendant physical, sociocultural, psychic, and other forms of dislocation"("Migration, Globalization, and Recent African Literature" 43-46). Ojaide asserts that migration, globalization, and the related phenomena of exile, transnationality, and multilocality have their bearing on the cultural identity, aesthetics, content, and form of the literary production of Africans, also noting that Africans born in the 1940s and 1950s write differently from those born after the 1960s and those Africans born abroad. He compared the two generations resident abroad, and explained that those born in the 1940s and 1950s grew up in Africa and went to school there. Their works are filled with nostalgia and set in concrete space and time. The vegetation, rivers, and other landscape features peculiar to those places are clearly delineated. The works are steeped in folkloric allusions and tend to eulogize ancient virtues. On the other hand, the post-1960-born Africans, sometimes children of emigrants, have vague memories of Africa, especially the traditional environment and society. What they write is very different from their older counterparts. Many in this group suffer from a psychic disconnection from the continent. These "children of postcolony," educated in the West, imagine Africa because they have not experienced the continent physically and culturally. By virtue of living outside their African homeland and in the West in an age of globalization, there are changes in subject matter, themes, language, style, and form in the various genres in which the writers engage themselves. Ojaide concludes that the phenomena of migration and globalization have an overwhelming impact on African literature, generating diverse perspectives of the evolving nature of African literature and the depiction of the contemporary African condition. 
I have also coined the term "techno-text" to refer to Post-indiginist work or African literature arising from the aesthetic ambiance of modern urban, global, technological culture, in contrast to creative writing mirroring the animist, agrarian environment of Africa's past echoed in folk tales, myths, praise songs, epic poetry, riddles and chants. In the past, the West was entertained by anthropological spectacles from Africa. And even till date Africa would rather be represented in the image of a primitive past than of modern industrial and technological progress. At the height of the frenzy, expatriate teachers and anthropologist (Africanist) scholars, critics and literary agents from the West goaded emergent African writers into providing ethnocentric texts as the unique signature of African literature. Later, Post-colonial criticism arose to hail such works as writing back in protest against colonialism. The notion that African culture is its folklore, including oral tradition, music, dance, rites and rituals, frozen in a static and idealized time and space, is entrenched in Africa's literary and critical benchmarks. As Walter Bgoya observes: "Little room is given to creativity that demands higher levels of education, higher levels of interpretation of contemporary realities ... not limited to traditional props and traditional genres" (283-292). The world has moved on from the age of folk tales, to that of global media, technology and popular culture, which requires new mode of representation.

The Post-indiginist approach entails a strategy to infuse literary language with present-day expressions, in order to enable the dialogue communicate current themes, symbols and diction. In sum, the dialogue of contemporary dramatic representation should depict the socio-psychology of characters, and the socio-history and socio-geography of their (contemporary) society. Post-indiginist literary language is to be informed by the following five considerations: 1) Language 
bears the tint of a user's experience as a medium of subjective communication; 2) A writer can express self in any preferred language, and may address any chosen audience: local or international; 3) The purpose of literature is to express any subject matter in a contemporary mode; 4) In an environment of cultural diversity, a writer may use language on the basis of competence and communicative criteria; and 5) African culture is not in assertion, in a multicultural context in which the reign of Western cultural universalism has receded (See "Language in Modern African Drama"). These criteria may be summarized as follows in analyzing Post-indiginist language usage in African plays: i) Literary language both betrays and represents the experience or background of a writer; ii) Writers would normally use a language in which they are most competent; iii) Literary language ought to reflect the contemporary environment and facilitate communal and crosscultural communication. Post-indiginist analysis is interested in answering the questions about why and how a writer uses a language out of the option, for instance, between English and mother tongue; and both of these questions are answered simply by examining the background of the writer.

\section{Two Post-indiginist Plays}

Some Africans that have written plays with the Postindiginist approach include Zakes Mda (Four Plays), Okoiti Omatatah (Chains of Junkdom), David Maillu (The Rainbow), Isaiah Ilo (Truth to Vipers, Jolie's Love Story, A Night Longer), Harry Hagher (Aishatu), and Ahmed Yerima (Hard Ground). In Aishatu, Harry Hagher uses Standard English plainly, without infusion of his native Tiv language. An explanation for this style may be traced to an upbringing in a family that had taken to western education and the church. A native of Kasar, in Katsina- Ala Local Government Area of Benue State, Nigeria, his father was a primary school headmaster in the 1930 s - 40s, and his mother learnt to read 
the English Bible because of her zeal for Christianity. As a child, Hagher attended the Christian Reformed Church with his family. He attended a mission secondary school in 1964 where he was introduced to Western drama through William Shakespeare's Julius Caesar, Hamlet, Romeo and Juliet, Macbeth and other plays. Hagher's other early exposure included the American Cowboy films and the Onitsha Market Literature. He had his degrees at the Ahmadu Bello University, Zaria, Nigeria, where he read English Language and Dramatic Arts up to a doctorate. As a playwright, Hagher uses the English language in which he is competent from his extensive education. Writing in his Tiv mother tongue or transliterating it in his English language works was probably out of Hagher's reach from the circumstances of his upbringing. His experience perhaps aptly illustrates the observation of Phanuel Egejuru that:

Many of the writers cannot express their ideas adequately in their mother tongue, because by the time the writer reaches the age of logical reasoning, his line of thinking is gradually being shaped by the foreign language, so that at the time he graduates from university all his academic thinking is done in the foreign language. Thus the African writer does not really think in his mother tongue to write in English as some suppose. He thinks and writes in English because of his colonial education (52).

Standard English is the variety used in the formal and informal speech and writing of the educated, whose spelling, grammar, pronunciation and vocabulary, is substantially uniform globally, though not without some regional differences. A literary use of Standard English in a current form guarantees a representation of the modern environment and facilitates cross-cultural communication. In the following 
example from Hagher's play, Aishatu, two educated characters, Apeh and Wadi, are engaged in a conversation:

Apeh: But this is not theory. It is real. Don't you realize when you bought your two houses in San Francisco and San Jose you were making a personal escape? Leaving everybody in Nigeria to perish while you took out our money and escaped?

Wadi: Don't forget I am not a politician. I abhor politics. I am a private hardworking citizen. We can't all be equal. Some of us work hard for our money. We should enjoy it. The danger in the country is these lazy politicians who want to be rich overnight for doing nothing.

Apeh: You are making a mistake. The danger in the country is the emergence of rich powerful individuals like you, who claim not to be politicians. You belong to all parties and all regimes - civilian and military. You push all governments by pretending to be friends with rulers and pretending to have the answers while you are concerned merely with how to make personal profit. Should the leadership prove progressive and refuse to dance to your tune - refusing to grant you special privileges - you cry for the leader's head.

Wadi: As for me I have no Godfathers in the system. I work for the money, and I must enjoy it the way I like. I am not preventing others from enjoying themselves.

Apeh: Why don't you enjoy yourself at Hill Station here, or Yankari or Obudu cattle ranch, Baguada Lake Hotel, to mention a few. The colossal sum of money you spend for three months each year at Churchill Hotel in London, and 
the Beverly Hilton comes from the nation's foreign reserves. Our prodigal lifestyles make us a beggar nation (Hagher 17-18).

Though the dialogue is in Standard English, the situation or experience presented is typically Nigerian. Clearly, the socio-geography is that of Nigeria; the socio-history is the well-known trend of political corruption in Nigeria; and the socio-psychology is that of a corrupt Nigerian businessman (Wali) and his outspoken critic (Apeh). The language is able to convey a contemporary Nigerian experience to both local and foreign audience, which might identify with a representation of the lavish and wasteful lifestyles associated with corrupt Africans. The playwright equally evokes the contemporary environment with allusion to American cities and reference to multicultural symbols, such as popular five star hotels in Nigeria and the United Kingdom. However, Hagher's language usage is too plain, considering that in the Poetics, Aristotle explained dramatic language as "language adorned with different kinds of ornament, separately in its various parts." Literary language is normally garnished with figures of speech, including metaphors, proverbs, and idioms devises which should be imbued with modern flavor in a modern play, in contrast to the traditional flavour of ethnotexts.

In 2006, Ahmed Yerima's play, Hard Ground won Nigeria's most prestigious and Africa's richest literary award the Nigeria Prize for Literature. And as may be deduced from the report of the panel of judges, the play earned the coveted award essentially due to its Post-indiginst style. The judges hailed the work as "writing of high thematic value and of national and international relevance as it affects not only the nation's deep concern with the current crises in the Niger Delta, but also Nigeria's international image" (Nigeria LNG 
Limited, Report of the Panel of Judges for the Nigeria Literature Prize, 2006). The panel was also impressed with the handling of the theme: "The writer deflects the play's focus from the political and economic genesis of the problem of the Niger Delta, to the emotional and spiritual impact on characters, and the shattering effect on close family ties" (NLNG Report 2006). The report further said:

Hard Ground is a powerful and psychologically wrenching tale that draws on the sad history of the Niger Delta, as well as its contemporary, real-life political drama. It also gives us the occasional but telling glimpse into the pathos of personal relationships and the drawn-out psychological suffering of its most vulnerable characters. The playwright controls the psychological response of the audience with the play's far- from clear-cut themes of right and wrong and the dubious political advantage of violence. But above all this, what the play effectively presents as the most valuable lesson of this war is the impact of the crisis on private lives (NLNG Report 2006).

It is noteworthy that in stating their approval of Hard Ground, the panel of judges made up of distinguished Nigerian Professors of literature, substantially praised the currency of the play's theme and its remarkable handling. This time the commendation did not go to a content of ethnic culture; instead the panel decried Nigerian writers' hangover with traditional appurtenances. This novel assessment might point to a coming shift in African literary taste in favour of Post-indiginist realism. Again, in the 2010 edition of the NLNG competition, the panel further endorsed the style, as Ahmed Yerima's Little Drops and Adinoyi Ojo Onukaba's The 
Killing Swamps, both of which were written in the style and equally addressed new perspectives of the current Niger Delta crisis, were finalists.

Hardground tells a story sketched from contemporary events in the Niger Delta of Nigeria. It is the story of Nimi's immediate and extended family, told to dramatise the playwright's perspective on the crisis in that region. The actions take place in the living room of Baba and Mama, whose only surviving child, Nimi - the protagonist, has been rescued from a mob that was about to lynch him. Nimi's assailants wanted his life to avenge their children whom he allegedly led to their early death. Nimi, a school dropout, protests his rescue from the creeks, where he has a rising profile as a leader among the militants fighting the cause of the marginalized Niger Delta people. The report from the creeks is that Nimi is in the forefront of the struggle, killing recklessly, murdering even his associates. The family (Mama, Baba, and Uncle Inyingifaa) gather around 18-year-old Nimi and demand an explanation of his role in the atrocities at the camp. Nimi reveals that the militant youths indulge in vandalism, terror, killing, maiming, and kidnapping in the name of the struggle. The victims are not only perceived enemies from outside the community, but also people from within - who might even be close family members or friends suspected as "vultures" - traitors, saboteurs. He describes how the boys under his command went about killing some "vultures": "The boys caught him, and hacked him to death, removing his head from behind as he sped. In the wildness, my boys ran into the shrine, pulled out the second man ... A stick was pushed through his anus until it came out in his bowels. We then dragged them back into the shrine, and burnt them" (Yerima 45-46). Mama is distressed over what the struggle has made of her son: "My child turns a monster before my death. How can I exorcise the evil spirit from my 
baby?" (9) Baba seems reticent in his attitude and response to his son's conduct and Nimi considers his father to be a coward because of his non-involvement in the struggle. Meanwhile, the whole community including Nimi's uncle, Inyingifaa, is demanding a revenge on Nimi, who is now regarded as a traitor having led the other boys to their death. For the same reason, the Don had placed a death sentence on Nimi. The Don is a shadow personality, yet his image looms large in the play. Nimi describes him as "the head of everything. Everybody. The man...He is supreme commander" (14). Believing that Reverend Father Kingsley, his paternal uncle (whom he made confessions to as a Priest) was the person who leaked the secret of the operation to the soldiers, Nimi accosts him and pins him down on the ground determined to slay him. But Inyigifaa saves the Reverend Father. A small group of individuals including Alabo, Tonye and Christy visit and deliver a gift to Nimi whom they praise for his exploits in advancing the struggle. Nimi is elated and head-swollen over the supposed honour. Later, he is discovered to be dying from a drink poison from the visitors. The family members run helter-skelter to revive him. Tingologo masquerade, which is a personification of death, appears to Nimi and accuses him of killing two fleeing men in front of his shrine, the penalty of which is death. Nimi is eventually spared, but he pays dearly with the lives of his beloved Pikibo and their unborn baby. There is irony in the preparation to receive the Don who promised the family a visit. Baba left enough money to prepare some delicious meal for the guest, and asked that he should be entertained very well in his absence. But instead Mama and Nimi get set to murder him once he steps into the house. Nimi is determined to avenge the killing of Pikibo and his unborn son, and Mama is out to avenge the execution of his brother on the orders of the Don. The Don arrives as announced, makes an entrance into the house and is slain 
directly by Nimi and Mama. But, alas, they discover that the dreaded leader of the struggle masked as the Don is in reality Baba.

Hard Ground addresses an urgent social problem directly, by examining the dynamics of a crisis that had become a major headache. The situation, as the play reveals, is a result of the greed, double-dealing and rivalry of the elite of Niger Delta, which sees them sending the boys against their opponents, and the boys themselves eventually growing up in virulence and consuming even their sponsors. The so-called struggle for resource control has metamorphosed into a behemoth consuming the people it sought to help.

Yerima told an interviewer that since a playwright ought to be relevant, proactive and preemptive, he wrote Hard Ground because, at that time, people were paying lip service to the issue of the Niger Delta. He felt that was dangerous; children could begin to kill their parents and the violence could get out of control. The play also raises the question about what kind of youths the Niger Delta was breeding when their childhood was already despoiled as child-soldiers. In his late teens Nimi is a school dropout, a know-nothing bragging about having a son outside wedlock. The play evokes the image of misguided youths with an illusion of bringing about change by means of violence. Alabo tries to dissuade Nimi about using violence as a means, saying: "Death is not working. The world does not listen to young men in headbands, with AK47 guns in the swamp. They will call them terrorists, guerrilla fighters, and both words mean killers, not heroes to them" (38). Mama also says: "Nimi needs to go back to school. I want him to finish his education. He cannot lead anything without education. All he has now is anger. Such anger leads one to destruction" (58).

The play resonates with universal lessons, although the action is based on a local Nigerian event. It is common to find 
elsewhere around the world, youngsters initiated into bloodletting, communities ravaged by resentment, the ugly consequences of selfishness, bigotry, suspicion, mistrust, greed, double-dealing and bloody rivalry. In Hard Ground, a Nigerian story is the means for reaching out to the world with important lessons. Yerima says, as though espousing Postindiginist realism:

We must begin to tell stories that will make people know more about us, rather than becoming cocooned in a small world. The new Nigerian dramatist should know that his predecessors like Wole Soyinka, J.P Clark, Femi Osofisan and so on, went and created stories that portrayed and introduced Nigeria. The process of introduction has gone. Now we are to look at the problem and discuss them. We may not find solutions; a play is not supposed to find solutions, it may suggest alternative ways (Adeoti $<$ sunnewsonline.com/new/specials/literaryreview/why-the-playwright-of- today-cant-shunpolitics-ahmed-yerima/>).

By looking at the sore Niger Delta problem and discussing it, the play itself was an important contribution toward dialogue, peace building and conflict resolution. Its message was driven home: A hater might make a victim of his object, but he equally ends up a victim of his hate. The crisis had an international dimension; it not only hurt the people of the Creeks, but also foreign oil workers who were often targets of kidnap by militants, and the global oil economy which suffered the serious impact of disruption of exports from Nigeria. In seeking social equilibrium in the Niger Delta, the play aired the grievances of the people, but at the same time denounced their excesses in demanding their rights. The playwright envisioned a Niger Delta region in which there was no oppression, injustice, or violence, but order, peace, 
tranquility and progress. It is likely that the play, whose stage performance toured the nine states of the Delta, helped in getting the people prepared to eventually accept the amnesty proposal of the Federal Government.

As contemporary Realism, the materials of Hard Ground are 1) a current social problem, 2) typical every-day characters, 3) an actual setting and 4) present-day word usage. All of these add up, to make the text a form of historical/cultural document. The play mirrors the conduct of the resource control agitation of the people of the Niger Delta. Following the discovery, prospecting and exploitation of crude oil in the Niger Delta, the region became a site of environmental pollution. Oil spillage crippled farming and fishing activities and polluted drinking water. There was dire lack of infrastructures, and unemployment, poverty, illiteracy and hardship became the lot of the people despite the fact that their oil was the mainstay of the national economy. In protest, guerrilla youth movements arose, such as the Niger Delta Peoples' Volunteer Force (NDPVF), Movement for the Emancipation of the Niger Delta (MEND), the Martyrs Brigade, Egbesu Boys and a host of others. The groups believed that their people were oppressed in the Nigerian federation and the solution was resource control under a federation of ethnic nationalities. Gradually, the agitation assumed the character of "intrigues, betrayals, espionage and counter-espionage, violence and blackmail" (Ogezi $<$ isaacogezi.blogspot.com/2008/02/pale-light-of-reality- inyerimas-hard.html? $\mathrm{m}=1>$ ).

If the event mirrored was an existing social problem, the dramatis-personae in the fictitious representation were also typical characters from the Niger Delta crisis. On November 10, 1995, Ken Saro Wiwa, a prominent writer and environmental activist from Ogoni in the Niger Delta was hanged along with eight others. A tribunal set up by the late 
military dictator, General Sani Abacha, convicted the Ogoni Nine for the murder of four pro-government traditional rulers. The four chiefs were beaten to death by a mob allegedly instigated by Saro Wiwa and the others. One of the victims who ran into a church for refuge was dragged out and killed gruesomely like the others. Their bodies were later burnt beyond recognition. Saro Wiwa was leader of the militant younger generation which regarded the elders who pioneered the struggle as weak and saboteurs. The elders were eventually nick-named vultures, and finally, four of them were killed on May 21, 1994.

The universe of the play is equally an existing one the Niger Delta territory, which was the site of the crisis. The Niger Delta area comprises of nine states of the Nigerian Federation, namely, Akwa Ibom, Bayelsa, Cross River, Delta, Edo, Imo, Ondo, Abia and Rivers. Despite the huge revenue accruing to the nation from the oil and gas deposits, a dire lack of infrastructure pervades the settlements in the Niger Delta creeks. Poverty is rife and millions do not have enough to eat; hundreds of thousands of children in the area die every year from easily preventable diseases. Over $95 \%$ of the people in the area lack access to clean water, sanitation, roads, electricity, health care system and a host of other basic infrastructural needs. The play evokes the world of "the swampy forest of green leaves and black oily soil...made up of wasteland and poverty" (Yerima, 11). Nimi describes his community as "The deadly swamp, the murky water, the heavy rain forests. The pockets of little villages separated by salty water...The black oil under the ground" (13). The religion, food and clothing of the people are all evoked in the play: Mama is a devotee of the water goddess as well as a Catholic; Nimi gets a meal of "unripe plantains mixed with oil, dried fish and shrimp" and his guests adorn him with "very expensive sewn traditional dresses with a bowler hat 
and a walking stick to match." Thus the play represents culture as well as history, even though its main objective is neither.

Finally, the diction of the play consists of words actually used in the crisis, such as "vulture," "the struggle," "bunkering," "resource control," and "true federalism," and more. Nimi says in the opening dialogue: "Now I shall be labelled a vulture. And any child with a knife can butcher me, tear me apart, or even hang me by the neck till life drips out of my body like river water, and I shall be left to die a slow painful death" (9). He continues: "They shall smoke me out like they do all vultures. They will track me down, slowly and steadily, I will be chased like a trapped rabbit. They shall fling me to the wolf boys who will spit on me first, like hungry crocodiles, their watery fangs shall await the bitterness of my flesh" (9). The playwright chose the words carefully to picture how victims were in reality killed in the crisis in reference. The agitation of the people of Niger Delta was referred to as "the struggle." This word equally features prominently in the play. For instance, in describing the recruitment of children by the warlords, Nimi says: "First you listen to what the elders say about the struggle. Even when in primary school. You live in pain, and then it sounds right to join the struggle" (12). In the actual crisis bunkering, or theft of crude oil from vandalised pipelines, was part of the activities of the militant groups. In the play Inyingifaa refers to this when he says: "My men were killed. Paraded on television that they were caught bunkering. But I never meddled in oil, only guns" (22 ). Also, the terms "resource control" and "true federalism" which often featured in public debates in the heat of the crisis also feature in the play. 


\section{Conclusion}

In Hard Ground, the playwright addressed a contemporary problem using contemporary characters, setting and diction. He did not have to rely on myth, ritual, legend, or history; nor use characters, setting or diction from the past allegorically to address a contemporary social problem. Of course a story from the past or work based on allegory, myth, ritual, legend or history can speak to an audience of today; after all, good stories are timeless. Nevertheless, a playwright should be a voice for his time, speaking with the imagery and materials from his time rather than depend only on accessories from the past to speak to the present. It should be restated in conclusion that the post-colonial world, the world of today, is one of new realities characterised by globalization, technology, multi-ethnicity, multiculturalism, transnationality and multilocality. It is not expected that in the face of these new realities, Africa's literary aesthetics will remain unchanging, frozen as representation of fossil folklore and traditions in ethno-texts. The aesthetics, including language, content, and form of Africa's contemporary literary production are bound to reflect the new environment as Post-indiginist realism or techno-texts.

\section{Isaiah U. Ilo}

Department of Theatre Arts

University of Abuja, Nigeria 


\section{Works Cited}

Adeoti Gbemisola. "Why the Playwright of Today Can't Shun Politics - Ahmed Yerima." The Sun, September 2, 2012 $<$ sunnewsonline.com/new/specials/literaryreview/why-the-playwright-of- today-cant-shunpolitics-ahmed-yerima/> (accessed 18 February 2013).

Amoda, Moyibi. FESTAC Colloquium and Black World Development (Lagos: Nigeria Magazine, 1978).

Ashcrof Bill, Gareth Griffiths, Helen Tiffin. The Empire Writes Back: Theory and Practice in Post-Colonial Literatures (Routledge, 2002).

Bgoya Walter. "The Effect of Globalisation in Africa and the Choice of Language in Publishing. International Review of Education, Vol. 47, No. 3/4, (Jul., 2001): 283-292.

Chennells Anthony. "Essential Diversity: Post-Colonial Theory and African Literature," (Brno Studies in English 25, S5. 1999) 109.

Egejuru Phanuel. Black Writers: White Audience (New York: Exposition Press, 1978).

Hagher Iyorwuese. Aishatu and Other Plays (Jos: Sagamu Publishers, 1996).

Ilo Isaiah. "Language in Modern African Drama," CLCWeb: Comparative Literature and Culture, Vol 8: Issue 4, (2006):

$<$ http://docs.lib.purdue.edu/clcweb/vol8/iss4/1>

Irele Abiola. Introduction, Collected Plays and Poems of J. P. Clark-Bekederemo (Washington: Howard UP, 1991).

Nigeria LNG Limited, Report of the Panel of Judges for the Nigeria Literature Prize, Drama Edition, 2006: $1<$ 
www.nlng.com/PageEngine.aspx?\&id=93>

(accessed 9 February 2013).

Ogezi Isaac. "The Plain Light of Reality in Yerima's Hard Ground." Blog: February 29, 2008 $<$ isaacogezi.blogspot.com/2008/02/pale-light-ofreality- in-yerimas-hard.html?m=1> (accessed 17 February. 2013).

Ojaide Tanure. "Teaching Wole Soyinka's Death and the King's Horseman to American College Students," College Literature, Vol 20, (1993): 210-214.

.......... "Migration, Globalization, and Recent African Literature," World Literature Today, Vol. 82, No. 2 (2008): 43-46.

Onwuemene Michael. "Limits of Transliteration: Nigerian Writers' Endeavors toward a National Literary Language," PMLA, Vol. 114, No. 5 (October., 1999): 1055-1066.

Oti Sonny. The Old Masters. Ibadan: Oxford University Press, 1977.

Sofola Zulu. "The Bogey of African Writer's Language Limitation in the Creative Process: The Core of the Matter," Literature and Society (Oguta: Zim PanAfrican Publishers, 1986).

Yerima Ahmed. Hard Ground (Ibadan: Kraft Books Limited, 2006). 